\title{
Effectiveness of Differentiated Instruction in Business English: The Lebanese Higher Education
}

\author{
Madoline Massaad, Léa Yahchouchi Abi Chaker
}

Department of Languages and Literatures, Holy Spirit University of Kaslik, Lebanon

\begin{abstract}
Mastering both the English language and the skills in business communication in Lebanon is needed for the students to succeed in their careers in this internationalized world. As diversity expands in higher education, the implementation of the traditional one-fits-all method steers students to failure in contrast to differentiated instruction's (DI) successful results. The purpose of this study is to determine the impact of DI in a blended learning environment and the traditional method on the productive proficiency of 180 students (94 in experimental groups and 86 in control groups) in two Lebanese universities having varied experiences and education during a period of three semesters. Mixed methods were utilized to collect and analyze the data. The findings revealed that the implementation of DI in a blended environment enhanced students' English productive skills.
\end{abstract}

Keywords-blended learning, Business English, differentiated instruction, productive skills.

\section{INTRODUCTION}

Although there are some differences in cultures, habits, traditions, and distinctive aspects among countries, English in the $21^{\text {st }}$ century possesses universal and prevailing characteristics. It has become the working or the bridge language of our time. Thus, English is used for disparate purposes and considerations: for acquiring and sharing information, for multicultural and international communication, and for conducting business, etc. (Teodorescu, 2013).

According to Sim (2013), Business English is generally unappreciated by researchers, in spite of its importance. It is only recently that its prominence has incited publishers and educators to shed light on the impact that English language proficiency has on students' future careers (Ellis \& Johnson, 1994; Frendo, 2005; Sim, 2013).

Students and fresh graduates who have little experience in the business world or are still unemployed acquire Business English communication skills chiefly from books. Hence, their knowledge and skills in Business English especially the productive ones are insufficient and theoretical rather than authentic and practical. Furthermore, these students are unaware of their language needs with regard to real-life communication in the various business contexts.

ISSN: 2456-7620
For students to be proficient and competent in Business English communication, Saqlain et al. (2012) and Teodorescu (2013) state that it is crucial to endorse suitable methodology for teaching Business English.

Researchers convey that the effectiveness of the educational system is encountering major challenges due to the lack of equity and quality of teaching and learning Business English. This situation is leading to gaps in achieving accuracy and fluency of the language productive skills among various groups of students (Brooks-Gunn \& Duncan, 1997; Tomlinson, 1999; DeCivita, Pagani, Vitaro $\&$ Tremblay, 2004). One of the major factors that hinders efficient and accurate speaking and writing has proven to be the use of the undifferentiated and traditional approach of teaching and learning which does not always help students who have mixed abilities to construct knowledge, satisfy needs, and arouse interests (Tomlinson, 1999; Valiande, 2010). As the aforementioned diversities in higher education increase, the task of teaching a mixedability class becomes more difficult, and instructors often struggle to determine their students' varying needs in the classroom (Gregory \& Kuzmich, 2004).

In her studies, Tomlinson (1999) found that one way to enhance students' verbal and writing proficiency is by investigating differentiated instruction strategies. She promoted the model of differentiated instructions where 
she based many of her ideas on Gardner's (1983, 1993, 2000) theory of multiple intelligences and Vygotsky's (1978) Zone of Proximal Development theory (ZPD). She states that students have different knowledge, learning styles, skills, and learning pace, and that they can effectively learn when instructors adjust to their needs and interests. Anderson (2007) argues that differentiated instruction is used by instructors to change the content, process, or product based on students' interest, readiness, and learning profile.

Nevertheless, the thorough awareness and reflection of the communicative competence (linguistics and nonlinguistics) is unlikely to be achieved during the limited time frame of a university semester that ranges between three and a half months to four months and conducted within classroom confinement (Ionel, 2011). Results from various researchers, such as Kenney and Newcombe (2011) and Garrison and Kanuka (2004), have shown that by implementing blended learning which combines faceto-face and online teaching and learning, students' communication competence improved during the semester when they extended their learning outside the limited environment of the classroom.

Thus, blended learning can offer differentiated learning options by differentiating the process and the environment. That is, by integrating face-to-face and online learning, students are allowed to have a certain degree of control over the how, when, and where of their learning.

\subsection{Problem Statement}

Mastering both the English language and the skills in business communication is needed for native and nonnative students to succeed in their careers (Ellis \& Johnson, 1994; Frendo, 2005; Sim, 2013). In Lebanon, it is essential for students to study Business English in order to communicate with people from foreign countries and/or with local companies that utilize English as a common language (Shaaban, 2006). Informal inquiry with English instructors in different universities in Lebanon has indicated that though Business English is taught in Lebanese universities, oral and written communication proficiency and accuracy of many of their students are not up to standards when faced with Business English contexts whether inside the classroom or the workplace.

We have taken notice of the problems faced by the majority of students when learning the course. Some of these problems are the irrelevance of materials found in Business English books to some of the students who are not majoring in business, the difficult content and vocabulary found in the books, the discrepancy between the theoretical knowledge (in classroom) and the practical knowledge (real-life business contexts), insufficient time to adequately practice the acquired knowledge, and the lack of students' motivation to obtain the needed knowledge when their needs are not being met. These observations are also supported by other colleagues who are disappointed by their learners' mediocre accomplishments.

Moreover, and according to informal interviews and questionnaires distributed to students who had taken Business English at different Lebanese universities, it was found that the students' abilities, interests, learning styles, learning profiles, and pragmatic awareness were not taken into consideration even when implementing the recent approaches and methods, such as task-based, communicative language learning, and cooperative approach. It is crucial to mention that the majority of these students are working and thus are engaging in real-life business situations/contexts.

Shaaban (2006), Valiande (2010), and Soprana (2017) state that neglecting students' interests, abilities, and styles while teaching business communication skills is negatively affecting the students' academic achievement, intercultural communication, and future careers. For the aforementioned reasons, the on-growing need for adequate and useful Business English instructions that mirror real-life experience and reflect students' needs along with the extensive practice of these skills should be taken into consideration when planning and teaching the Business English course.

As mentioned earlier, the differentiated instruction approach, which has proved to boost students' verbal and writing proficiency, might remediate to the problems encountered by both instructors and learners of Business English. There exists nonetheless a lack of empirical proof in Lebanon regarding the significance of differentiated instruction in teaching and learning Business English, and how students' experiences with the approach influence both their academic and career achievement. Therefore, a study of this topic is justified and will likely serve the research community as it reduces the current gap in the literature regarding the effectiveness of implementing differentiated instruction in Business English in Lebanon and provides as well instructors with a possible model(s) to teach the course

This article addresses the following research question: To what extent will differentiated instruction in a blended learning classroom, in Lebanon, contribute to the learners' enhancement of the English oral and written skills for business purposes, in comparison to the traditional onefits-all method? 


\section{LITERATURE REVIEW}

In an attempt to answer this question, this article investigates the effectiveness of developing the students' English proficiency in higher education when implementing the strategies of differentiated instruction in a business context. For this purpose, the literature review addresses the fundamental development that Business English has undergone from only memorizing phrases and vocabulary into developing and realizing the skills required to use the learned Business English and to handle any business communication whether written or/and verbal.

\subsection{Business English}

Frendo (2005) states that "Business English is an umbrella term for a mixture of general everyday English, general business English, and English for Specific Purpose (ESP)" (p. 7).

Due to many developments that Business English had undergone, there is a critical need to modify not only the idea of Business English and the circumstances in which it is educated and learnt nowadays, but also the structure or framework that encompasses its conceptualization, construction, learning and teaching methods, and finally assessment and evaluation (Frendo, 2005; Zhang, 2007).

As stated by Bhatia and Bremner (2012), an extensive perception of the purpose and consideration of the business conventions or processes can be achieved if the person transcends the restraints of the text/context and acknowledges diversified discourses, voices, and actions. All these factors have an essential part in the construction of a definite mode of discourse in the framework of the organization

Therefore, Business Communication Skills or Business English is created to fulfil student's needs in the workplace. Yasuda (2011) emphasizes that, to be a competent business professional, students have to establish an adequate awareness of their genre to identify what is appropriate within the genre. Students should know the communicative occurrences regularly utilized by group of people of a specific community having shared communicative aspirations. This teaching approach is adopted so students are capable of using this understanding when communicating with their audience (Yasuda, 2011).

Salmani Nodoushan (2011) and Yasuda (2011) state that students' awareness should extend to what is viable in Business Communication Skills at the word, sentence, and communication level. It is the instructor's responsibility to structure the lessons to ensure that students incorporate what sentence or/and terminology are utilized in Business Communication Skills and how English is applied and adapted in conversation. They continue saying that many Business English materials and courses for non-native students presume that they possess the intermediate knowledge of English to count on. But in reality, it is not always the case, so instructors have to provide extra materials for the students who are below the intermediate level or above it, which is not always implemented due to the extensive themes and objectives found in the curriculum that should be covered in a short period of time (Frendo, 2005; Sim, 2013). The students have to be exposed to authentic business communication, such as writing of different business correspondence among various areas of genres, direct teaching of the genre's standards and rules, and ample opportunities for language production.

Thus, students have to be taught the essential language and social conventions. For this reason, business speaking communication and business writing communication will be thoroughly examined in the following section.

According to Frendo (2005), to teach business speaking skills, there are six types of speaking contexts students have to be taught: socializing, small talk, speaking on the phone, presentations, meetings, and negotiations. Usually not all the speaking skills are taught adequately and thoroughly within the limited hours per semester (Nehme, 2013). For the sake of this article, speaking on the phone, job interviews, and presentations are chosen. Though the other forms which are socializing, small talk, and negotiations are not thoroughly addressed and applied, they are still embedded in the chosen types. In addition, there are many written types to be taught in Business English classrooms which are correspondence, contracts, reports, curriculum vitae, and memos, among others.

In accordance to Bagaric and Djigunovic (2007), Bhatia and Bremner (2012), and Frendo (2005), Business English does not only revolve around the language but also around its use in different contexts that mirror real-life situations. For this to be attained, it is crucial to examine the concept of communicative competence that has as its subcomponents the linguistic competence, the discourse competence, and the intercultural competence.

\subsection{Communicative Competence}

Various methods of dividing the components of communicative competence have been analysed throughout the years, back when instructors were principally concerned in teaching only the components. In general, Business English instructors have to particularly concentrate on three basic components: linguistic, discourse, and intercultural competencies (Frendo, 2005). For this study, the Bachman and Palmer (1996, 2010) 
model will be implemented. The reason for implementing this model is that its strategies administer metacognitive principles that plan, achieve, control, and correct the diverse language activities of receiving, interacting, producing, and reflecting (Bagaric \& Bremner, 2007).

According to Bachman and Palmer (1996), communicative language ability is affected by the language user's characteristics; such as language ability, affective conception, and contemporary knowledge. The most critical of those is language ability which encompasses two extensive scopes: strategic competence and language knowledge.

To Bachman and Palmer, language knowledge is divided into three essential components organizational knowledge, pragmatic knowledge, and strategic knowledge that complete each other to fulfil communicative language application (Bachman \& Palmer, 1996). Bagaric and Djigunovic (2007) have reported that in this model, organizational knowledge is concerned about skills having a power over formal language construction; that is grammar and textual knowledge.

To begin with, grammatical knowledge encompasses various and not separate fields of knowledge including morphology, phonology, semantic, syntax, and graphology (Bachman \& Palmer, 1996; Frendo, 2005). These areas permit identification and construction of grammatically accurate production/sentences in addition to the understanding of their suggested and presented content in opposition to memorizing a fixed formation and then reproducing it.

The second component of the organizational knowledge in Bachman \& Palmer (1996) is the textual knowledge which allows the understanding and production of written or spoken texts. It includes knowing the protocol of connecting utterances or sentences to form texts (Bachman \& Palmer, 1996; Frendo, 2005). In other words, it is knowledge of the rhetorical system, cohesion, or/and conversational organization that consist of ways to initiate, maintain, and conclude conversation. They elaborate by saying it consists of the understanding and the capacity to handle sentence order, taking into account many elements: topic, given/new, cause/effect, natural sequencing, and the capacity of handling and structuring the discourse (coherence, cohesion, organization of themes, rational ordering, register, and style). Furthermore, Grice's (1975) maxims have to be respected either in written or spoken sentences. The four maxims are quality, quantity, relevance, and manner which ensure that the individual's contribution is true, not more than necessary, relevant to what is being discussed and ordered in a way to avoid ambiguity.

Bachman \& Palmer (1996), Frendo (2005), and Ionel (2011) express that pragmatic knowledge, the second main component of language knowledge, indicates the ability to create and explain conversation. It consists of two fields of knowledge (Bachman \& Palmer, 1996). The first field is the knowledge of pragmatic usage to articulate adequate language function and to decipher this significant communicative influence of discourse or utterance referred to as functional knowledge. The second field is the knowledge of sociolinguistic system to generate and decipher language utterances that are suitable in a specific context (Bachman \& Palmer, 1996).

Finally, strategic knowledge is realized as a collection of metacognitive elements which allow participation of language users to set a goal, to assess communicative schemes, and finally to plan (Bachman \& Palmer, 1996; Zhang, 2017). They clarify that goal setting is concerned about determining what the individual will do if he/she wants to use the language or undergoes a test.

The model was modified in 2010 to integrate cognitive strategies (Altun, 2017; Bachman \& Palmer, 2010; Frendo, 2005; Zhang, 2017). According to Bachman and Palmer (2010), the central aspects are language ability that constitutes the strategic competence and language knowledge, while the minor aspects consist of affective schemata, topical knowledge, personal characteristics, and cognitive strategies.

For students to succeed in their future careers, they should acquire skills (linguistic and non-linguistic) needed in the business world, regardless of their major; that is why reallife situations should be depicted to the extent possible in the classroom through the implementation of studentcentred teaching methodology for teaching Business English a away from the teacher-centred style (Frendo, 2005; Nehme, 2013; Soprana, 2017; Tomlinson, 1999).

\subsection{Teaching Methodologies for Business English}

Many approaches and methods have been used for English teaching and learning, such as the Direct Method, Grammar Translation Method, and Audio-Lingual Method. Though these methods had some benefits in improving students' language performances, they were unsuccessful in providing students with effective knowledge, skills, and experience to utilize the language for practical use and daily communication (Frendo, 2005; Koosha \& Yakhabi, 2013).

There was a shift to adopt and embrace the Communicative Language Teaching (CLT) model because it accentuates 
students' communicative competence (Celce-Murcia, Dornyei \& Thurrell, 1993; Frendo, 2005; Hymes, 1972; Koosha \&Yakhabi, 2013; Teodorescu, 2013).

Communicative competence is the students' competence to accurately convey what they intend to say in the target language and auspiciously attain authentic communication in real-life contexts (Bachman \& Palmer, 1996; Frendo, 2005; Lightbown and Spada, 1999; Power, 2003). This is done when students acquire both the grammatical as well as the pragmatic competences of the target language (Bachman \& Palmer, 1996, 2010; Frendo, 2005; Hedgcock, 2002). Instructors have used the CLT approach which intends to improve the ability of students to communicate in the target language.

Many theorists such as (Frendo, 2005; Shehadeh, 2005) argue that CLT has two essential forms (weak and strong), and both are implemented in Business English. The weak form of CLT concentrates on "what" is to be learned in which present, practice, and produce (PPP) is a conventional approach emerged from Audiolingualism in the 1950s (Frendo, 2005; Hyde, 2013); then PPP was a part of CLT as a teaching method (Richards \& Renandya, 2002; Richards \& Rodgers, 2001; Frendo, 2005; Willis, 1990). While the strong form stresses on "how" students can learn. It is argued that learning the language is achieved through negotiating the meaning in authentic communication which is done via tasks in the classroom environment as in role playing. Here, language is learned to fulfil a definite outcome. Unfortunately, the strong form of the CLT is not frequently implemented in the classroom environment due to many reasons, such as the extensive amount of educational curriculum objectives to be achieved at the end of the academic cycle, lack of instructors' awareness and experience to effectively implement the CLT strategies within the confinement of the classroom, and the large number of students which presents a challenge for the instructor in planning and orchestrating his/her communicative classroom (Nehme, 2013; Koosha \& Yakhabi, 2013).

Richards \& Renandya (2002) explain the main phases of PPP as follows:

\subsubsection{Presentation}

In this phase, the instructor begins by presenting a definite feature of language such as a language function or/and grammatical structure enclosed in a context with the support of examples like audio, dialogues, role plays, and videos in addition to techniques such as the use of realia and brainstorming.

\subsubsection{Practice}

In practice, a situation is described by the instructor where students have to practice the indicated pattern either through individual, pair, or group work. Here accuracy of form of the students' work is checked by the instructor.

\subsubsection{Production}

It is the last stage in which the instructor introduces a task or activity to students who are expected to utilize the practiced form(s). The task can be a case for role play, a subject to write, or any assignment that supposedly requires the learned language model to be used.

According to Carless (2009), PPP is effective because the instructor has a clear and specific role, in addition to the ability to control the lesson's pace. It also emphasizes the instructional aspect of instructors. Many critics (Ellis \& Johnson, 1994; Hyde, 2013) have stated that the PPP method emphasizes instructors' actions and does not stress on language meaning or student communication or interaction. Here the instructor is the knower, the student is tabula rasa, and behaviour adjustment through comprehensive and ample practices is the means to learning. The authors continue their argument by indicating that activities are often given at the last phase, and thus students only have the opportunity to analyze and experiment with language at the production final stage.

As diversity escalates in higher education, the one-size-fits all traditional teacher-centred teaching design leads students to failure, not only academically but also professionally. Baumgarlner, Caffarella, \& Merriam (2007) argue that students in higher education are more diverse than students at school due to their different and diverse life and educational experiences. Nevertheless, not enough attention is given to the instructional and educational planning to meet this diversity.

This diversity in the classrooms, as Heacox (2012) and Subban (2006) explain, has been a challenge for conscientious instructors, driving them to seek innovative effective teaching methods or/and strategies to cope with this heterogeneity. Active and receptive instructors, according to Standford, Crowe, and Flice (2010), have been implementing differentiation for many years in their classrooms via various forms and patterns. Still, not many instructors have been enthusiastic and ready to implement it, as it needs excessive preparation time and effort (Subban, 2006; Van Casteren et al., 2017).

In Lebanon, the majority of higher educational institutions are still applying the traditional PPP teacher-centred approach because of the comprehensive curriculum demands and the compact educational schedule which do not allow opportunities for students to entirely experience the communicative approach (Nehme, 2013; Shaaban, 
2018). Nehme (2013) reports that English learning and teaching, especially teaching grammar, follows the traditional teacher-centred approach which is known as the grammar instruction method. Therefore, students are passive and lack chances in communication and interaction.

\subsection{Differentiated Instruction}

Differentiated instruction is based on approaches supporting the notion that every person learns or acquires knowledge differently and at a different pace; consequently instructors should examine new approaches and strategies for their instructions to be differentiated in order to meet all student interests and needs in the classroom environment (Heacox, 2012; Subban, 2006; Udell, 2018).

Tomlinson (1999, 2005) and Tomlinson \& Imbeau (2010) hypothesize that the application of differentiation in the classroom will be through the modification of curriculum components which are content, process, product, and learning environment. Tomlinson (2005) demonstrates that differentiating content constitutes the educational materials, and how students acquire the taught materials. She proposes that what is given has to stay nearly regular and steady for students with instructors modifying how students acquire the assigned content to attend to students' needs. Some examples of differentiating content would be by giving texts at various reading levels of difficulty, administering texts on audiotape, providing audio/visual presentations, and implementing small group instruction for the purpose of emphasizing content or teaching it again if needed (Tomlinson, 2005). In addition and according to Heacox (2002), the content can be differentiated when the students are given the opportunity to select the subtopic from the main subject or unit, and then each student delivers the information included in his/her selected subtopic.

To acknowledge students' various interests, learning profiles, and readiness levels, process could be differentiated (Tomlinson 1999, 2005). Anderson (2007) asserts that process differentiation is how students reach the point of comprehending and assimilating concepts, skills, or facts. Effective strategies for process differentiation may consist of tiering exercises to different levels of difficulty for developing and increasing each student's learning experience.

Products as asserted by Tomlinson (2005) are the ultimate assessment that permits students to manifest the extent of their perception and how well they display and exhibit the acquired skills and knowledge after considerable pieces of instructions. Differentiating product has to provide students diversified ways for exhibiting mastery of general learning purposes.

Furthermore, differentiated instruction, theoretically, is established from Vygotsky's (1978) constructivist theory learning perspective where zone of proximal development (ZPD) is a fundamental attribute of the theory. As a consequence of differentiation, students are presented to some extent to a higher expectation that is however suitable to every distinctive students' ZPD. Hence, the theory is beneficial for students of mixed and disparate needs. Additionally, for students to progress academically and professionally, they have to be engaged in constructive interaction and discussion with an educated knowledgeable adult (instructor) and/or competent peer(s) within a classroom community ambiance which is the basis of the sociocultural aspect of Vygotsky's (1978) constructivist theory.

In addition, Tomlinson's differentiated instruction integrates Gardner's (2011) multiple intelligence. Gardner argues that intelligence is not simple but multifaceted. According to Gardner's (2011) nine intelligences, instructors must intently differentiate their pedagogical methods and instructions to correspond to students' intelligence fields in order to afford them with the highest competent learning experiences. Moreover, each student has a distinctive learning style and profile that influences how she/he acquires and assimilates the given information.

It is worth mentioning that acquiring the communicative competence effectively and adequately is unlikely to be attained thoroughly due to the time constraints and the adaptation and implementation of the traditional face-toface one-fits-all method of teaching and learning. That is why, and through the use of technology, the blended learning model is introduced in this study to engage students in the learning experience and to try to enhance their critical thinking abilities to deepen their learning process (Morgan, 2014).

\subsection{Blended Learning}

Cleveland-Innes and Cleveland-Innes and Wilton (2018) and Thorne (2003) define blended learning as a normal development or progress of learning. It presents a solution to the difficulties of conforming learning and progress to learners' needs. It provides a chance for integrating the contemporary and technological progress afforded by online learning with the cooperation and participation presented in the appropriate face-to-face traditional learning environment which is promoted and improved by implementing the experience, knowledge, and face-to-face contact of the instructor (Cleveland-Innes and Wilton, 2018). 
The theme of blended learning is described by Graham (2006) as merging of face-to-face context which is synchronous and encompasses interaction among individuals with information communication technology context (ICT) which is asynchronous, and where individuals work independently. A great deal of research has proved that implementing blended learning techniques in classes has succeeded in improving students' learning results and outcomes (Cleveland-Innes and Wilton, 2018; Twigg, 2003 a; Dziuban et al., 2006; Lim \& Morris, 2009; Northey, Chylinski, \& Govind, 2015).

For an improved efficient learning outcome to be achieved in this new era of technological advancement, an essential method has to be designed and implemented to increase the interactions of student to student and student to instructor (Pletka, 2007). Sendal et al. (2008) states that using social networking such as Wikis, blogs, Skype, etc. has been found to be considerably effective in the teaching and learning process. These collaborative tools provide students with the necessary skills to face today's workforce. For this study, Google Classroom and Skype are used as the technological tools in teaching the Business English course in a blended learning context. This method can also prove to be extremely efficient in times of crises, as online teaching had, for example, to be swiftly implemented all over the world recently in light of the novel COVID_19 pandemic.

\section{METHODOLOGY}

\subsection{Research Method}

The study is an experimental research in which the researcher manipulates one variable which is the independent variable, controls, and measures the dependent variables in order to establish a cause-effect relationship between them (Creswell, 2011). In this study, the differentiated instruction is considered as the independent variable in which its strategies of differentiating content, process, and product serve students' interest, needs, and learning profiles. The last-mentioned components are considered as the treatment variable conditions manipulated to cause an outcome or a dependent variable which is students' productive skills (written and oral) progress in the present study.

This study seeks to investigate if implementing differentiated instruction in a blended learning environment would deal with the problems faced by nonnative English students in higher educational settings. The problems addressed here encompass students' productive skills. The results of the experimental groups are compared with the results of the control groups to examine if any difference is noted when implementing differentiated instruction.

\subsection{Research Environment}

For this study, 180 students registered for the Business English course participated in the experiment. They were divided into three semesters in two universities; the first is located in Mount Lebanon, and the second is located in Beirut. Cluster sampling was applied in the experiment in which each semester the researcher randomly selected two groups (clusters) out of four groups that were registered for this course. There were two classes in the morning and two classes in the evening, and one class was chosen randomly from each shift by the use of an online random picker (miniwebtool.com).

The students in each semester were divided into two groups: the experimental groups in which the intervention was administered by implementing differentiated instruction and the control groups in which no interference was applied. The teaching and learning process in the latter groups followed the traditional one-fits-all PPP method.

Based on the literature review and the experimental research, this study might infer what will happen if strategies of differentiated instruction in a blended learning environment are implemented.

The ages of the participants ranged from 20-35 years old, and they were of different genders, educational fields, and cultural backgrounds. As a result of these discrepancies, they had varying English proficiencies. Though the universities are in Mount Lebanon and Beirut, the students came from various Lebanese areas and governorates, as it was documented from the registrar files.

Moreover, the processes in experimental research as suggested by Kemmis et al. (2014) are best undergone with co-observers/co-participants to ensure reliable, fair, and valid research. The Business English course for all the groups was taught by the same instructor/researcher and another expert instructor for 13-14 weeks per semester, so the variables of the instructors and course time for each semester are the same for all the groups.

\subsection{Research Design}

This study employs a mixed research method aiming at triangulating qualitative and quantitative data tools obtained from pretest and posttest, students' grades, and the two instructors' observations to collect the relevant data from the undergraduate students who are taking Business English.

\subsubsection{Procedures of the Study}


The table below shows the overall procedures that were implemented for teaching Business English for both groups.

Table 1: Procedures of the Study

\begin{tabular}{l} 
Control Group One-Fits- \\
All Model in the \\
Classroom \\
\hline Present: The instructor \\
presented the theme or \\
concept, read the text and \\
found the concept \\
embedded in the text, in \\
addition to providing \\
examples using different \\
techniques.
\end{tabular}

Practice: The instructor described a situation in which students were to practice the emphasized pattern and checked students' work for accuracy.

Production: The instructor presented a task to students in which they were expected to utilize the form(s) just practiced (role play, writing task, or any task that used the language pattern or vocabulary learned).

\section{Differentiated Instruction} In Blended Learning Environment

\section{Differentiation of content:} Introducing the topic and tasks, thus preparing students for the task. Linking various texts and resources (according to interests, levels and learning profiles) and uploading them in Google Classroom to be later checked online.

Differentiation of process: Using of tiered activities, using of independent learning strategies (cooperative or problembased), with the implementation of appropriate grouping of students depending on the tasks, levels or interests, providing various levels of scaffolding to students, and engaging students in writing business correspondence (emails depending on their grouping) and in oral communication (interviews, phone conversations, and presentations).

\section{Differentiation of product:} Delivering of the presentation either online, by Skype, or in the classroom and providing students with a variety of assessment choices, for example preparing formal or informal presentations either in groups or as individuals pretests were administered employing the Independent tTest in SPSS to examine if there was any significant difference among all the participants of the groups. At the end of the semester, the posttest grades of both groups were also admitted using the Independent t-Test in SPSS to investigate which learning and teaching method was more effective and appropriate for the students to achieve the highest learning outcome of the course.

Furthermore, the students' grades of all the groups were entered for a quantitative analysis using the Independent tTest in the Statistical Package for the Social Science (SPSS) to compare the grades of the experimental groups with the grades of the control group. The goal of grade comparisons was to examine the degree of improvement in the students' oral and written performances in a specific context in English Business communication skills after the introduction of the differentiated instruction using different strategies in a blended learning environment.

\section{RESULTS AND DISCUSSION}

\subsection{Results}

\subsubsection{Quantitative Data Analysis}

\subsubsection{Pretest and Posttests}

The first quantitative data were the pretest and posttest scores of the control and experimental groups in each semester. SPSS 23 was employed to conduct both descriptive and inferential statistical analysis of students' test scores in which T-test was utilized.

First, the written and oral pretest scores were administered to examine if there was any significant difference between the groups before any intervention was applied. This section investigates separately the aforementioned scores for each semester.

As displayed in Table 2 below, it can be concluded that there was no significant difference between the pretest written scores of both groups as the Sig (2-tailed) was 0.507 for the written and 0.914 for the oral, which is greater than 0.05 for both values.
Appropriate data analysis techniques had to be implemented for analysis. The grades of both groups' 
Table 2: Pretest Written Spring 2018
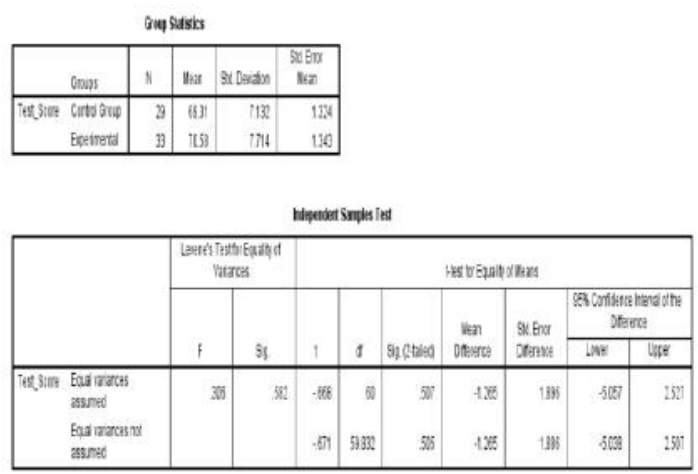

Pretest Oral Spring 2018
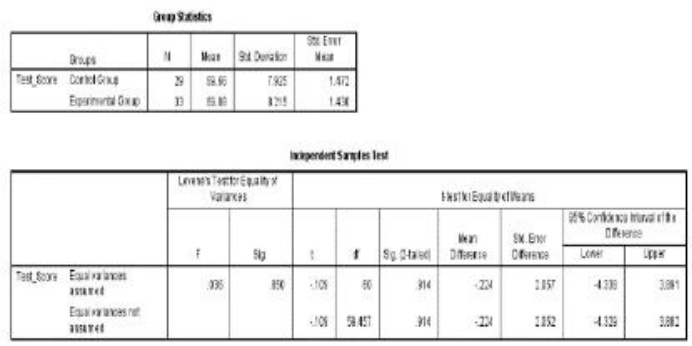

Moving to Fall 2019, it was also proved that there was no significant difference in written and oral pretest scores for the control and experimental groups which are presented in Table 3. The Sig (2-tailed) was $0.0752>0.05$ for the written and $0.586>0.05$ for the oral pretest indicating that statistically there was no significant difference in the students' oral and written English skills between the groups before the intervention.

Table 3:Pretest Written Fall 2019
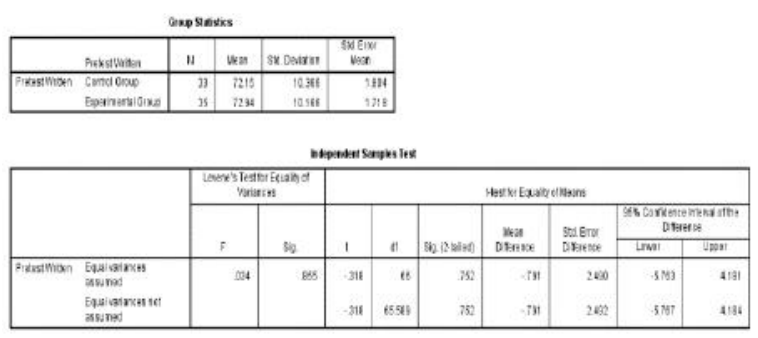

Pretest Oral Fall 2019
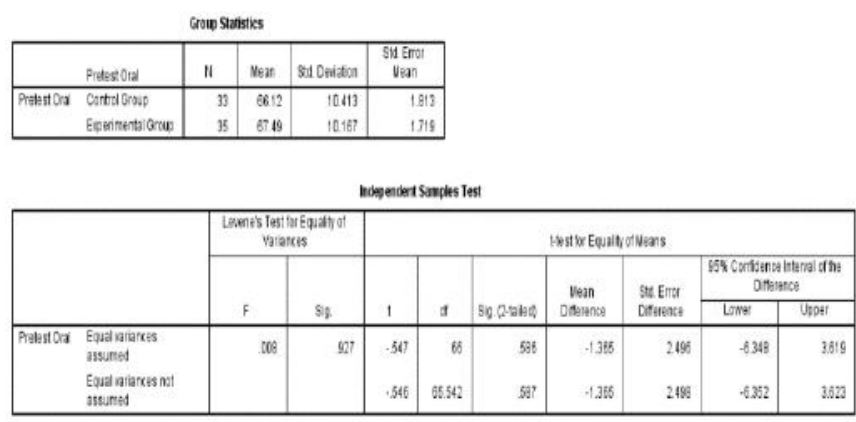

ISSN: 2456-7620
As for Spring 2019, it was confirmed that there was no significant difference in the students' written skills (Sig (2tailed) is $0.651>0.05$ ) as well as their oral skills (Sig (2tailed) is $0.680>0.05$ ) before the experiment as shown in Tables 4 below.

Table 4: Pretest Written Spring 2019
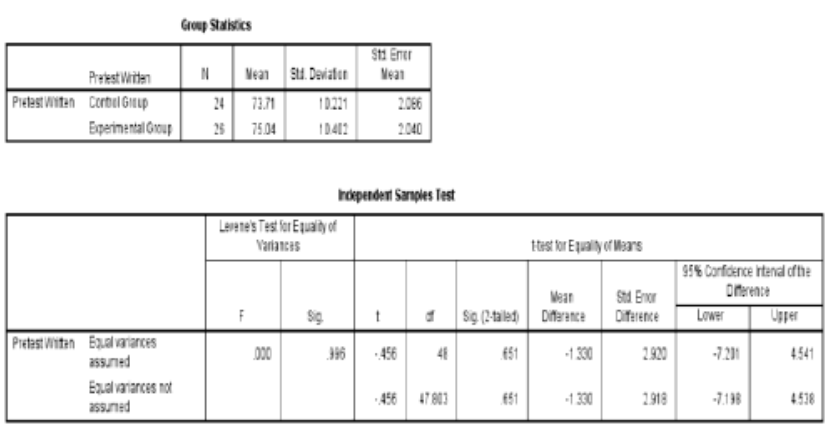

Pretest Oral Spring 2019
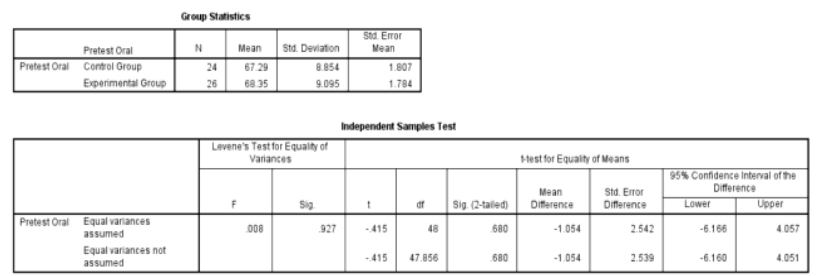

Moreover, written and oral posttests were conducted as well at the end of the semester to investigate students' progress levels in their English written and oral skills. The tests were also used to examine if there was any significant difference between both groups in each semester, especially after the intervention on the experimental groups where differentiated instruction in a blended learning environment was implemented.

Regarding Spring 2018, Table 5 shows that Sig (2-tailed) is $0.017<0.05$ indicating a significant difference in students' writing skills between the groups. Referring to the table, group statistics show that the mean for the experimental group is 80.79 which is higher than the control group's mean of 75.97 .

\section{Table 5: Posttest Written Spring 2018}
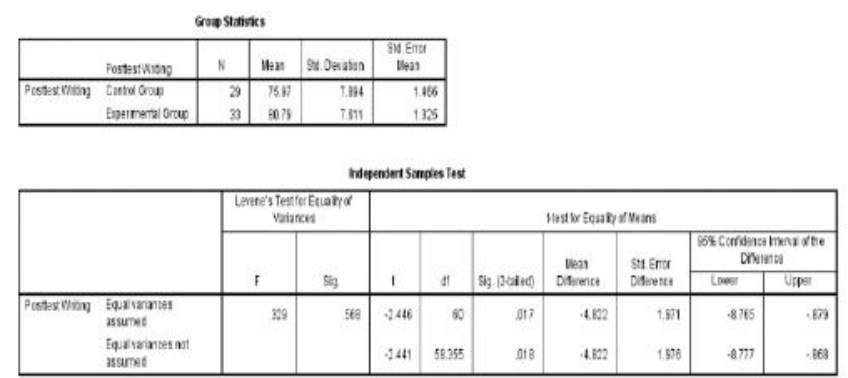
While analyzing the oral posttests, Table 6 exhibits an apparent difference in students' oral skills with the Sig (2tailed) being 0.001 , which is less than 0.05 . Also, the mean in the group statistics shows the considerable discrepancy between the groups' average with the experimental score being 78.52 and the control group score being 71.83 .

Table 6: Posttest Oral Spring 2018
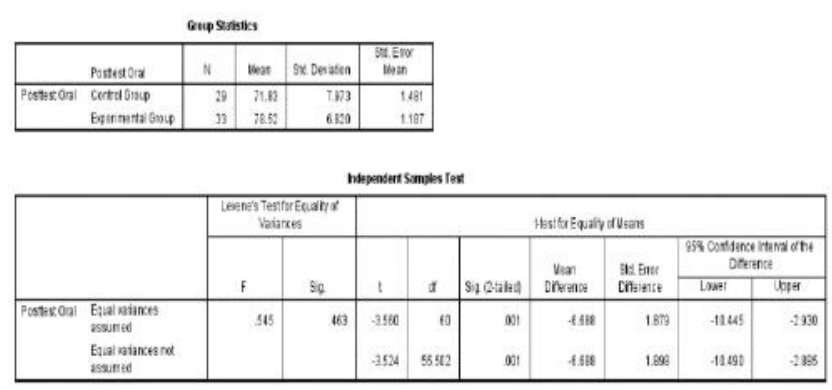

For the Fall semester 2019, there was significance difference between both in the written and oral posttests for the two groups. In regards to the writing skills in Table 7, the Sig (2-tailed) is 0.03 which is less than 0.05 , and the Sig (2-tailed) in Table 8 for the oral posttests is 0.000 which is also less than 0.05 , indicating that the difference between the groups' means are not presumed to be due to chance but presumed to be probably due to the manipulation administered by implementing the differentiated instruction in a blended environment.

Table 7: Posttest Written Fall 2019

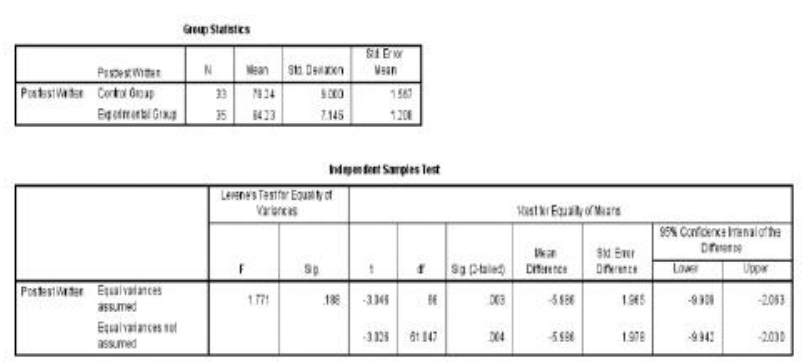

Table 8: Posttest Oral Fall 2019
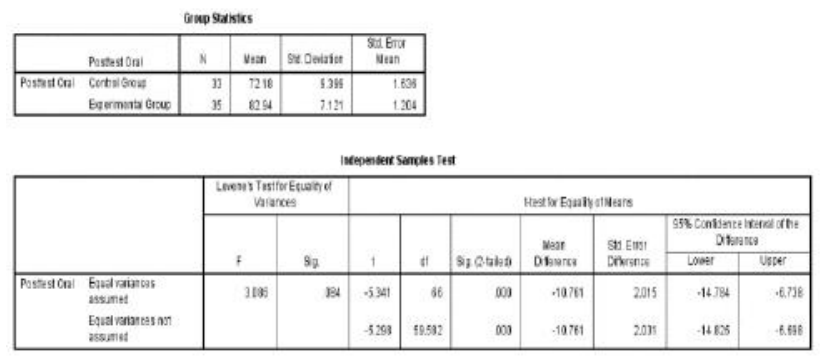

What accentuated the aforementioned hypothesis was the recurrent significant difference recorded in the Spring semester of 2019 in another university in which the Sig (2tailed) is $0.002<0.05$ for the written posttests (Table 9) and $0.000<0.05$ for the oral posttests (Table 10).

Table 9: Posttest Written Spring 2019
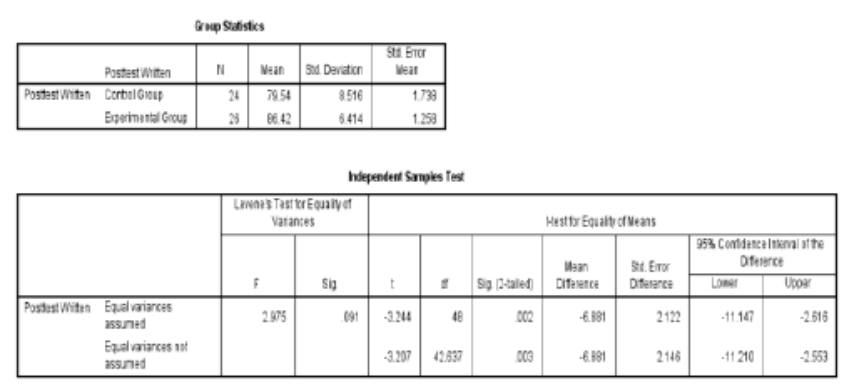

Table 10: Posttest Oral Spring 2019
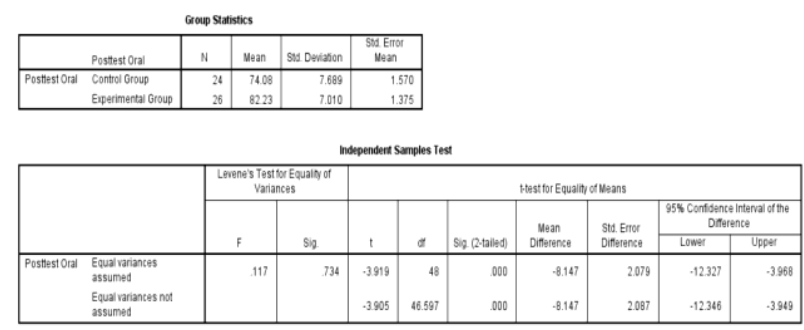

Further quantitative analysis besides the pretests and posttests was accomplished by analyzing the semester's grades.

\subsubsection{Test Grades}

The students had four tests: Test 1, Midterm exam, Test 2, and Final exam. On the one hand, the Midterm and Final exams were the same for both groups in each semester abiding by the university's policy of having common exams for the same course. The exams tested the knowledge acquired regarding the themes learned and the communicative competence or language knowledge attained. Following Bachman and Palmer' framework of communicative competence (1996), language knowledge was divided into organizational knowledge and pragmatic knowledge

On the other hand, Test 1 and Test 2 differed in both groups in which the experimental groups were subjected to differentiated strategies in blended learning environment. While using the blended learning, students were exposed to various instructional materials suitable for their levels, interests, and styles. To continue with the idea of differentiated strategies in a blended environment, students were exposed to face-to-face and online communication mirroring real-life business interactions that occur in the business world. This strategy was employed using the acquired learned materials for the purpose of using English 
outside the confinement of the classroom whether in oral and/or written discourse.

For this section, the scores of each test were administered in the Independent Sample Test in which Leven's Test for Equality of Variances in SPSS was utilized to examine the existence of significant difference. As displayed in the table11 below regarding the Sig (2-tailed) and the tests' averages and after analyzing the acquired data of each test for the three semesters, it can be deduced that there is a significant difference in the students' oral and written performances of the experimental groups in comparison to the students' oral and written performances in the control groups.

Table 11: Test Averages of Spring 2018

\begin{tabular}{|l|l|l|l|}
\hline Tests/Exams & $\begin{array}{l}\text { Control } \\
\text { Group } \\
\text { Average }\end{array}$ & $\begin{array}{l}\text { Experimental } \\
\text { Group } \\
\text { Average }\end{array}$ & $\begin{array}{l}\text { Sig } \\
\text { tailed) }\end{array}$ \\
\hline Test 1 & 71.00 & 75.18 & $0.045<0.05$ \\
\hline Midterm & 72.03 & 79.00 & $0.002<0.05$ \\
\hline Test 2 & 73.55 & 80.76 & $0.001<0.05$ \\
\hline Final & 73.03 & 81.85 & $0.000<0.05$ \\
\hline
\end{tabular}

Test Averages of Fall 2019

\begin{tabular}{|l|l|l|l|}
\hline Tests/Exams & $\begin{array}{l}\text { Control } \\
\text { Group } \\
\text { Average }\end{array}$ & $\begin{array}{l}\text { Experimental } \\
\text { Group } \\
\text { Average }\end{array}$ & $\begin{array}{l}\text { Sig } \\
\text { tailed) }\end{array}$ \\
\hline Test 1 & 70.42 & 75.17 & $0.047<0.05$ \\
\hline Midterm & 71.24 & 78.11 & $0.004<0.05$ \\
\hline Test 2 & 74.42 & 81.23 & $0.002<0.05$ \\
\hline Final & 72.55 & 82.26 & $0.000<0.05$ \\
\hline
\end{tabular}

Test Averages of Spring 2019

\begin{tabular}{|l|l|l|l|}
\hline Tests/Exams & $\begin{array}{l}\text { Control } \\
\text { Group } \\
\text { Average }\end{array}$ & $\begin{array}{l}\text { Experimental } \\
\text { Group } \\
\text { Average }\end{array}$ & $\begin{array}{l}\text { Sig } \\
\text { tailed) }\end{array}$ \\
\hline Test 1 & 70.21 & 75.65 & $0.039<0.05$ \\
\hline Midterm & 72.00 & 79.12 & $0.004<0.05$ \\
\hline Test 2 & 75.29 & 84.23 & $0.000<0.05$ \\
\hline Final & 74.46 & 83.62 & $0.000<0.05$ \\
\hline
\end{tabular}

After examining the test averages, it could be deduced that all the groups were improving, but the improvement of the experimental group students was consequential when correlated with the students' averages in the control group.
This result may indicate that the method and/or strategy used for teaching the course, which in this case was differentiated instruction in a blended environment, was beneficial for acquiring and practicing the given materials in comparison to the one-fits-all PPP method implemented in the control group.

Besides quantitative analysis, the qualitative observational field notes were also used in regard to investigating the students' level of improvement in the productive skills when the strategies of differentiated instruction in a blended environment were implemented.

\subsubsection{Qualitative Data Analysis}

\subsubsection{Observation: Field Notes}

For the analysis and comparison to be reliable and valid between the control and experimental groups, only the Midterms and Finals exams were examined as they were similar for both groups.

According to Bachman and Palmer's framework (1996) of communicative competence, language knowledge is divided into three components: organizational knowledge, pragmatic knowledge, and strategic knowledge.

As a reminder, the organizational knowledge is divided into grammatical knowledge and textual knowledge. The data obtained from the exams were manually decoded regarding the components of the organizational knowledge focusing on vocabulary, syntax, morphology, semantic, cohesion, coherence, in addition to phonology that was taken from the final oral test which was the job interview.

After coding and categorizing the components to be examined, the disruptions of these components were investigated for each student in both groups in each semester. To further clarify the process, when a student made one or many mistakes in one of the components, it was considered a disruption. Each component has rules and guidelines to be abided by, and if not, it is considered as breaking the component's rules. This was accomplished to detect students' acquired productive skills based on the learning and teaching method/strategy applied.

First, the disruptions or breakdown of students' organizational knowledge in the Midterm exam per semester are presented in the tables below: 
Table 12: Disruptions of Organizational Components of Spring 2018 Midterm

\begin{tabular}{|l|l|l|l|l|}
\hline Groups & $\begin{array}{l}\text { Lexicon } \\
\text { Vocabula } \\
\text { ry })\end{array}$ & $\begin{array}{l}\text { Syntax/Morpho } \\
\text { logy }\end{array}$ & $\begin{array}{l}\text { Cohesi } \\
\text { on }\end{array}$ & $\begin{array}{l}\text { Coheren } \\
\text { ce }\end{array}$ \\
\hline Control & 18 & 20 & 20 & 17 \\
\hline $\begin{array}{l}\text { Experimen } \\
\text { tal }\end{array}$ & 13 & 11 & 11 & 10 \\
\hline
\end{tabular}

Table 13: Disruptions of Organizational Components of Fall 2019 Midterm

\begin{tabular}{|l|l|l|l|l|}
\hline Groups & $\begin{array}{l}\text { Lexicon } \\
\text { Vocabula } \\
\text { ry }\end{array}$ & $\begin{array}{l}\text { Syntax/Morphol } \\
\text { ogy }\end{array}$ & $\begin{array}{l}\text { Cohesi } \\
\text { on }\end{array}$ & $\begin{array}{l}\text { Coheren } \\
\text { ce }\end{array}$ \\
\hline Control & 21 & 24 & 23 & 19 \\
\hline $\begin{array}{l}\text { Experimen } \\
\text { tal }\end{array}$ & 13 & 10 & 12 & 10 \\
\hline
\end{tabular}

Table 14: Disruptions of Organizational Components of Spring 2019 Midterm

\begin{tabular}{|l|l|l|l|l|}
\hline Groups & $\begin{array}{l}\text { Lexicon } \\
\text { Vocabula } \\
\text { ry }\end{array}$ & $\begin{array}{l}\text { Syntax/Morphol } \\
\text { ogy }\end{array}$ & $\begin{array}{l}\text { Cohesi } \\
\text { on }\end{array}$ & $\begin{array}{l}\text { Coheren } \\
\text { ce }\end{array}$ \\
\hline Control & 16 & 16 & 18 & 14 \\
\hline $\begin{array}{l}\text { Experimen } \\
\text { tal }\end{array}$ & 11 & 9 & 9 & 8 \\
\hline
\end{tabular}

Analyzing these tables, it can be inferred that there were disruptions of organizational knowledge which included the grammatical and textual components in both groups. Nevertheless, the total number of disruptions was higher in the control groups than those found in the experimental groups. It may indicate that the means by which the learning materials or contents were given to the experimental groups was more effective than the control group.

Furthermore, the same components were examined for any disruptions in the Final exams for the groups at the end of each semester and are displayed below:
Table 15: Disruptions of Organizational Components of Spring 2018 Final

\begin{tabular}{|l|l|l|l|l|}
\hline Groups & $\begin{array}{l}\text { Lexicon } \\
\text { Vocabula } \\
\text { ry) }\end{array}$ & $\begin{array}{l}\text { Syntax/Morpho } \\
\text { logy }\end{array}$ & $\begin{array}{l}\text { Cohesi } \\
\text { on }\end{array}$ & $\begin{array}{l}\text { Coheren } \\
\text { ce }\end{array}$ \\
\hline Control & 13 & 14 & 14 & 12 \\
\hline $\begin{array}{l}\text { Experimen } \\
\text { tal }\end{array}$ & 4 & 4 & 4 & 3 \\
\hline
\end{tabular}

Table 16: Disruptions of Organizational Components of Fall 2019 Final

\begin{tabular}{|l|l|l|l|l|}
\hline Groups & $\begin{array}{l}\text { Lexicon } \\
\text { Vocabula } \\
\text { ry }\end{array}$ & $\begin{array}{l}\text { Syntax/Morphol } \\
\text { ogy }\end{array}$ & $\begin{array}{l}\text { Cohesi } \\
\text { on }\end{array}$ & $\begin{array}{l}\text { Coheren } \\
\text { ce }\end{array}$ \\
\hline Control & 16 & 17 & 16 & 12 \\
\hline $\begin{array}{l}\text { Experimen } \\
\text { tal }\end{array}$ & 5 & 4 & 5 & 3 \\
\hline
\end{tabular}

Table 17: Disruptions of Organizational Components of Spring 2019 Final

\begin{tabular}{|l|l|l|l|l|}
\hline Groups & $\begin{array}{l}\text { Lexicon } \\
\text { Vocabula } \\
\text { ry }\end{array}$ & $\begin{array}{l}\text { Syntax/Morphol } \\
\text { ogy }\end{array}$ & $\begin{array}{l}\text { Cohesi } \\
\text { on }\end{array}$ & $\begin{array}{l}\text { Coheren } \\
\text { ce }\end{array}$ \\
\hline Control & 12 & 11 & 13 & 10 \\
\hline $\begin{array}{l}\text { Experimen } \\
\text { tal }\end{array}$ & 3 & 3 & 3 & 2 \\
\hline
\end{tabular}

The tables demonstrate that students in the experimental groups in the three semesters showed a significant awareness and improvement in using the organizational knowledge in their written Final exams compared to the students' slight progress in the control groups. Moreover, it can be deduced that there was an apparent influential improvement of the students' written skills in the experimental groups when compared to their Midterm written performances.

Proceeding to the analysis of the oral skills, qualitative data of the job interview conducted at the end of the semester was analyzed. The observed students' performances were distributed among the values ranging from very weak, weak, adequate, good, and excellent as introduced in the tables below: 
Table 18: Job Interview Spring 2018

\begin{tabular}{|l|l|l|}
\hline Value & $\begin{array}{l}\text { Control } \\
\text { Group }\end{array}$ & $\begin{array}{l}\text { Experimental } \\
\text { Group }\end{array}$ \\
\hline $\begin{array}{l}\text { Very } \\
\text { Weak }\end{array}$ & 3 & 0 \\
\hline Weak & 8 & 1 \\
\hline Adequate & 10 & 8 \\
\hline Good & 7 & 18 \\
\hline Excellent & 1 & 6 \\
\hline
\end{tabular}

Table 19: Job Interview Fall 2019

\begin{tabular}{|l|l|l|}
\hline Value & $\begin{array}{l}\text { Control } \\
\text { Group }\end{array}$ & $\begin{array}{l}\text { Experimental } \\
\text { Group }\end{array}$ \\
\hline Very Weak & 7 & 0 \\
\hline Weak & 6 & 0 \\
\hline Adequate & 13 & 9 \\
\hline Good & 6 & 20 \\
\hline Excellent & 1 & 6 \\
\hline
\end{tabular}

Table 20: Job Interview Spring 2019

\begin{tabular}{|l|l|l|}
\hline Value & $\begin{array}{l}\text { Control } \\
\text { Group }\end{array}$ & $\begin{array}{l}\text { Experimental } \\
\text { Group }\end{array}$ \\
\hline Very Weak & 4 & 0 \\
\hline Weak & 5 & 0 \\
\hline Adequate & 11 & 6 \\
\hline Good & 3 & 14 \\
\hline Excellent & 1 & 6 \\
\hline
\end{tabular}

As illustrated in these tables, the students' performances in the control groups varied, shifting more to the adequate/average level. It also showed that there were many students whose values were very weak and weak with a few good and excellent values in the oral productive skills. Whereas, most students in the experimental groups shifted more to the good rating value, and while the rest were divided into either adequate or excellent. Even in the range of excellent, the number of students in the experimental group was considerably higher than the number of students of the control groups.

Through observing the written field notes regarding the analyzed codes, students in the experimental groups had compelling oral performance. They revealed raised awareness regarding the use of appropriate terms which were syntactically correct. In addition, their ideas were precise, clear, and coherent; even the succession of the ideas was smooth and intelligible and supported with corroborative details for clarification. Also, their verbal and nonverbal skills were exceptional, for their confidence was high which affected their prosodic features. To further explain the last point, they held appropriate eye contact in conjunction with appropriate gestures. In addition, their prosody was efficient as they maintained clear voice and articulation with vocal varieties used to show interest and enthusiasm concerning questions. Their body language and facial expressions showed their confidence and comfort when they were interviewed.

\subsection{Discussion}

The mixed method was utilized by analyzing the collected data quantitatively and qualitatively to strengthen and validate the findings. Quantitative tools such as pretests/posttests and students' grades were used in addition to the qualitative observational field notes to investigate and answer the research question: To what extent will differentiated instruction in a blended learning classroom contribute to the learners' enhancement of the English oral and written skills for business purposes in comparison to the traditional one-fits-all method?

After analyzing and connecting the various findings from the quantitative and qualitative tools, it was revealed that the strategies implemented in the experimental groups using the differentiated instructions in a blended learning environment were immensely effective and useful in developing and improving students' productive skills. Their oral and written performances developed and increased through the tasks and tests/exams. Their results were juxtaposed with the results of the control groups' students who were subjected to the one-fits-all PPP method of teaching and learning. There was a significant discrepancy between the two groups in each semester. Though many students in the control groups had improved, their progress and the level of language mastery were insignificant and inadequate to face the current demands of English proficiency and accuracy in the workplace. They still made mistakes pertaining to grammar such as incorrect verb tense, subject/verb agreement, question formation, etc. Furthermore, and although they had learned the suitable words and expressions used in the different registers, they failed to competently use them when needed, In contrast, they used wrong lexis and even colloquial expressions translated from their Arabic mother language. 


\section{CONCLUSION AND RECOMMENDATIONS}

A fundamental factor of the study was to find out if there was any relationship between students' achievements and the use of differentiated instruction in blended environment. It was accomplished by comparing qualitatively and quantitatively the results and performances of the experimental groups, exposed to differentiated instructions, with those of the control groups, who followed the traditional PPP one-fits-all mode. The findings of the study provided many explanations and clarifications about the effect of utilizing differentiated instruction in a blended environment.

Concerning the research question, the findings of the quantitative tools affirmed the notion that using differentiated strategies which take into consideration students' needs and interests increased their achievement in all English skills especially the productive ones (writing and speaking) which are the components investigated in this study. As analyzed previously, there was consequential difference between the control groups and the experimental groups as the Sig (2-tailed) was less than 0.05 in all the tests, and the experimental groups in all the semesters acquired higher grades than the control groups.

Furthermore, the findings of the qualitative data analysis strengthened the quantitative results. The anecdotal notes affirmed the significant improvement and awareness of the experimental groups' organizational knowledge (grammatical knowledge and textual knowledge) adopted by Bachman \& Palmer (1996), compared to the slight progress registered in the control groups. The results of the observation supported that employing differentiated mixed strategies appropriately dealt with students' various needs, styles, and levels, which eventually increased their achievements.

For this reason, Lebanese universities ought to regularly appraise their pedagogical methods and strategies to cope with students' needs, technological advancements, and Lebanese and international business markets' requirements. Businesses are struggling with students/graduates who are saturated with theoretical knowledge but lack communicative, technological, and social skills. Extensive exposure to authentic materials and real-life practices in using the target language must be included in Lebanese universities' language curricula for the purpose of fulfilling the students' various needs and expectations. To achieve this, it is recommended that universities in Lebanon cooperate with the Ministry of Higher Education to reconsider universities' curricula and implement pedagogical methods and procedures that adhere and conform to the demands of the workplace environment with English as an international language Students will hence increase their chances to be fully equipped with the fundamental competence to communicate fluently and accurately in different contexts.

\section{REFERENCES}

[1] Altun, M. (2015). The Evolvement of the Term 'Communicative Competence'. International Journal of Social Sciences \& Educational Studies, 16.

[2] Anderson, K.M. (2007). Tips for teaching differentiating instruction to include all students. Preventing School Failure, 51(3), 49-53.

[3] Bachman, L. F., \& Palmer, A. S. (1996). Language testing in practice: Designing and developing useful language tests (Vol. 1). Oxford University Press.

[4] Bachman, L. F., Palmer, A. S., \& Palmer, A. S. (2010). Language assessment in practice:

Developing language assessments and justifying their use in the real world. Oxford: Oxford University Press.

[5] Bagaric, V. \& Mihaljević Djigunović, J. (2007). Defining communicative competence. Metodika, 8(1), 94- 103.

[6] Baumgartner, L., Caffarella, R. S., \& Merriam, S. B. (2007). Learning in adulthood: A comprehensive guide.

[7] Bhatia, V., \& Bremner, S. (2012). English for Business Communication. Language Teaching, 45(4), 410-445.

[8] Brooks-Gun, J. \& Duncan, G.J. (1997). The effects of poverty on children. The Future of Children: Children and Poverty, 7: 55-71.

[9] Carless, D. R. (2009). Revisiting the TBLT versus PPP debate: Voices from Hong Kong. Asian Journal of English Language Teaching.

[10] Celce-Murcia, M., Dörnyei, Z., \& Thurrell, S. (1993). A pedagogical framework for communicative competence: content specifications and guidelines for communicative language teaching. In Deseret Language and Linguistic Society Symposium (Vol. 19, No. 1, p. 3).

[11] Cleveland-Innes, M., \& Wilton, D. (2018). Guide to blended learning.

[12] Creswell, J. (2011). Educational Research: Planning, conducting and evaluating quantitative and qualitative research. Pearson.

[13] De-Civita, M. Pagani, L., Vitaro, F. \& Tremblay, R. E. (2004). The role of maternal educational aspirations in mediating the risk of income source on academic failure in children from persistently poor families. Children and Youth Services Review, 26: 749-769.

[14] Dziuban, C.D., Hartman, J.L., \& Moskal, P.D. (2004). Blended learning. Educational Center for Applied Research Bulletin, 7, 12(1): 41-49. 
[15] Ellis, M., \& Johnson, C. (1994). Teaching business English (pp. 25-38). Oxford.

[16] Frendo, E. (2005). How to teach business English. Harlow, UK: Longman.

[17] Gardner, H. (1983). Frames of mind: The theory of multiple intelligences. New York: Basic Books.

[18] Gardner, H. (1993). Frames of mind: The theory of multiple intelligences. New York: Basic Books.

[19] Gardner, H. E. (2000). Intelligence reframed: Multiple intelligences for the 21 st century.

[20] Garrison, D. R., \& Kanuka, H. (2004). Blended learning: Uncovering its transformative potential in higher education. Internet and Higher Education, 7(2), 95-105.

[21] Graham, C.R. (2006). Blended learning systems: Definition, current trends, and future directions. In Handbook of Blended Learning: Global Perspectives, Local Designs: 321. San Francisco, CA: Pfeiffer Publishing.

[22] Gregory, G. \& Kuzmich, L. (2004). Data driven differentiation in the standards-based classroom. Corwin Press.

[23] Grice, H. P. (1975). Logic and conversation. In Speech acts (pp. 41-58). Brill.

[24] Heacox, D. (2012). Differentiating instruction in the regular classroom: How to reach and teach all learners (Updated anniversary edition). Free Spirit Publishing.

[25] Hedgcock, J. S. (2002). Toward a socioliterate approach to second language teacher education. The Modern Language Journal, 86(3), 299-317.

[26] Hyde, C. (2013). Task-based language teaching in the business English classroom (Doctoral dissertation).

[27] Hymes, D. H. (1972). On Communicative Competence. In Pride, J. B., \& Holmes, J. (Eds.), Sociolinguistics, 269-293. Baltimore, USA: Penguin Education, Penguin Books Ltd.

[28] Ionel, S. (2011). Pragmatic competence-essential to developing business students' communication skills. The Bucharest Academy of Economic Studies: 61-73.

[29] Kemmis, S., McTaggart, R., \& Nixon, R. (2014). Introducing critical participatory action research. In The action research planner (pp. 1-31). Springer, Singapore.

[30] Kenney, J., \& Newcombe, E. (2011). Adopting a blended learning approach: Challenges, encountered and lessons learned in an action research study. Journal of Asynchronous Learning Networks, 15(1), 45-57.

[31] Koosha, M., \& Yakhabi, M. (2013). Problems associated with the use of communicative language teaching in EFL contexts and possible solutions. International Journal of Foreign Language teaching and research, 1(2), 63-76.

[32] Lightbown, P. M., \& Spada, N. (1999). How languages are learned: Oxford University Press New York.

[33] Morgan, D. (2014). Pragmatism as a paradigm for social research. Portland State University, OR, USA, 20(8): 1045 1053.

Retrieved from: https://doi.org/10.1177/1077800413513733

[34] Nehme, N. F. (2013). Is the Grammar-Instruction Approach an Old-Fashioned Method in Comparison to the Communicative Approach in Non-Native Contexts? A Case Study of Students and Teachers' Perceptions.
[35] Northey, G., Bucic, T., Chylinski, M., \& Govind, R. (2015). Increasing student engagement using asynchronous learning. Journal of Marketing Education, 37(3), 171-180.

[36] Pletka, B. (2007). Educating the net generation. Santa Monica, CA: Santa Monica Press LCC.

[37] Power, T. (2003). Communicative language teaching: The appeal and poverty of communicative language teaching. TESOL Quarterly, 25(7), 87-96.

[38] Richards, J. C., \& Renandya, W. A. (Eds.). (2002). Methodology in language teaching: An anthology of current practice. Cambridge university press.

[39] Richards, J. C., \& Rodgers, T. S. (1987). Communicative language teaching. Approaches and Methods in Language Teaching. New York: Cambridge UP.

[40] Richards, J., \& Rodgers, T. (2001). Approaches and methods in language teaching, 2.

[41] Salmani Nodoushan, M. A. (2011). Temperament as an Indicator of Language

[42] Achievement. Online Submission, 5(4), 33-52.

[43] Sendall, P., Ceccucci, W. \& Peslak, A. R. (2008). Got web 2.0? A review of web 2.0 tools for the information systems curriculum. The Proceedings of ISECON, Phoenix

[44] Senior, R. (2010). Connectivity: A framework for understanding effective language.

[45] Shaaban, K., \& Ghaith, G. (2006). The theoretical relevance and efficacy of using cooperative learning in the ESL/EFL classroom. TESL Reporter, 38(2), 14-28.

[46] Sim, M. (2013). Ups and downs of teaching Business English terminology. University of Oradea.

[47] Soprana, V. (2017). A theoretical outline of the importance of cross-cultural and pragmatic awareness in the business scenario. BERT: Porto Alegre, 8(1): 101-121. Retrieved from: http://dx.doi.org/10.15448/2178-3640.2017.1.27462.

[48] Stanford, P., Crowe, M. W., \& Flice, H. (2010). Differentiating with technology. Teaching exceptional children plus, 6(4), 4.

[49] Subban, P. (2006). Differentiated instruction: a research basis. International Education Journal, 7(7), 935-947.

[50] Teodorescu, A. (2013). Traditional vs. modern approaches in business English teaching in the economic field. Knowledge Horizons-Economics, 5(2), 153-156.

[51] Thorne, K. (2003). Blended learning: How to integrate online and traditional learning. London: Kogan Page.

[52] Tomlinson, C. (1999). The differentiated classroom: responding to the needs of all learners. Alexandria, VA: ASCD.

[53] Tomlinson, S. (2005). Education in a post welfare society. McGraw-Hill Education (UK).

Tomlinson, C. \& Imbeau, M. (2010). Leading and managing a differentiated classroom. Alexandria, VA: ASCD. USF Information Technology. (2009). Retrieved from University of South Florida: https://www.usf.edu/it/about-us/itnews/skype-for-business.aspx.

[54] Twigg, C. A. (2003a). Improving learning and reducing costs: Lessons learned from Round 1 of the Pew grant program in course redesign. Troy, NY: Center for Academic 
Transformation. Retrieved from http://www.thencat.org/PCR/R1Lessons.html

[55] Udell, S. (2018). How differentiating instruction helps students connect to learning. Ed Surge.

[56] Valiande, S. (2010). Differentiated teaching in mixed ability classrooms, learning processes and effectiveness. University of Cyprus, Nicosia, CY.

[57] Van Casteren, W., Bendig-Jacobs, J., Wartenbergh-Cras, F., van Essen, M., \& Kurver, B. (2017). Differentiëren en differentiatievaardigheden in het primair onderwijs.

[58] Vygotsky, L.S. (1978). Mind and society: The development of higher mental processes. Cambridge, MA: Harvard University Press.

[59] Yasuda, S. (2011). Genre-based tasks in foreign language writing: Developing writers' genre awareness, linguistic knowledge, and writing competence. Journal of second language writing, 20(2), 111-133.

[60] Zhang, Z. (2007). Towards an integrated approach to teaching business English: a Chinese experience. English for Specific Purpose, 26: 399-410. 